\title{
Review: \\ Forest management and conservation practices in Ethiopia: Opportunities and constraints
}

\author{
BEKELE TONA AMENU \\ Jimma University. P.O.Box, 307, Jimma, Ethiopia. `email: bekelet20007@gmail.com, bekele.tona@yahoo.com
}

Manuscript received: 21 November 2018. Revision accepted: 26 December 2017.

\begin{abstract}
Amenu BT. 2018. Review: Forest management and conservation practices in Ethiopia: Opportunities and constraints. Asian J For 2: 77-82. Ethiopia has various and diversified natural resources. Forests are one of the most valuable resources of the country that have several benefits for society. It constitutes various social, economic, and other uses. This review identified that forests are an important part of the environment and economy of a nation. When managed well, forests provide clean air and water, homes for wildlife, beautiful scenery, places for recreation and more than 5,000 products that are used every day. Forest resources and forest lands should be managed and used on sustainable basis to fulfill the social, economic, cultural and spiritual needs of the present and future generations. By its nature, forestry is concerned with maintaining the quality of various non-market benefits. In forest management, trees are harvested for a variety of reasons including improving the health of the forest; controlling the types of trees that grow on the site; attracting certain wildlife species; providing a source of income for the landowner; producing paper, lumber and numerous other forest products; and improving access to the area for hikers, hunters and other recreational users. There are some constraints in forest conservation and management, including addressing poverty and forest governance by promoting forest ownership and access rights; promoting greater recognition of the rights of local and indigenous groups; and giving greater attention to land tenure, ownership, and rights-to-resource. Conversely, the greatest opportunities in forest management lie in forest and land restoration.
\end{abstract}

Keywords: Forest management, forest, sustainability, conservation, constraints, opportunities

\section{INTRODUCTION}

Forests are home to at least 80 percent of the world's remaining terrestrial biodiversity and are a major carbon sink to mitigate global climate. Forests also help to maintain the fertility of the soil, protect watersheds, and reduce the risk of natural disasters, such as floods and landslides.

Forests contribute to the livelihoods of more than 1.6 billion people globally. Forests and forest products industries are important sources of economic growth and employment, with the value of global forest products traded internationally reaching US\$270 billion, of which developing countries account for more than 20 percent. Worldwide, forest industries provide employment (both formal and informal) for approximately 50 million people. Covering 26 percent of the Earth's land surface, forests play a significant role in realizing the Millennium Development Goals (MDGs) of halving the number of people living in absolute poverty by 2015 . In addition to the lumber and wood products industry, the gathering and marketing of hundreds of forest products, such as forest fruits, fuelwood, and medicinal products, constitute an economic activity of enormous scale. As human populations grow and countries around the world become more affluent, the demand for wood products, both solid wood and pulp and paper also will increase (FAO 2006).

Unfortunately, rural development strategies often neglect forests because forests have been mistakenly viewed as being outside the mainstream of agricultural development. This situation is worsened by the increasing rate of destruction of remaining forests across the world. The continuing global deforestation and degradation threaten biodiversity, forest-related ecological services, and rural livelihoods.

Multiple-use forest management (MFM) for timber, non-timber forest products, and environmental services is envisioned by many as a preferable alternative to timberfocused regime. It is praised as a more equitable strategy of satisfying the demands from multiple stakeholders, ecologically more friendly harvesting approach, and a way of adding more value to forests. MFM thus represents a common and prime management objective under the sustainable forest management (SFM) paradigm (Wunder et al. 2007).

Ethiopia has various and diversified natural resources. Forests are one of the most valuable resources of the country. It is one of the natural resources that have several benefits for society. It constitutes various social, economic, and other uses. In addition, forests provide benefits such as medicine, fuel, protection, tools and other uses (Wang 2004). Forest land is also important for watershed protection, soil and water conservation, wildlife conservation and recreational value (Eshetu 2004). This paper review forest management and conservation in Ethiopia with focus on the constraints and opportunities in the practice. 


\section{FOREST RESOURCE MANAGEMENT AND ITS PURPOSES}

Forest resources provide numerous direct and indirect economic benefits. They are beneficial for the production of incense, gums, resin, bamboo, and honey. Forest resources and forest lands should be managed and used on sustainable basis to fulfill the social, economic, cultural and spiritual needs of the present and future generations. By its nature, forestry is concerned with maintaining the quality of various non-market benefits (Wang 2004).

Many tropical forests have been fragmented into small patches, and forest structure and regeneration have been disturbed due to this fragmentation (Cabin et al. 2002). Human-induced disturbances, mainly via grazing activities or tree harvesting, strongly influence the regeneration success of woody species and in turn determine the vegetation structure and composition of these forests (Cotler and Ortega-Larrocea 2006). As a result, the persistence of the remnant forest patches and their indigenous species in many areas are threatened.

Forest management is a combination of economic, ecological and social practices. Human and natural systems comprise a complex, dynamic combination of intertwined practices with the capability of constructing, reproducing and reorganizing information. A current trend favors and recommends social science-based multidisciplinary approaches in studying the socio-ecological systems of small-scale forestry (Fischer et al. 2010 and Leskinen et al. 2006). Sociology and other disciplines have widened the traditional view built upon forest ecology and engineering (Fischer et al. 2010). This wider view has been one driving force behind organizational changes in institutions engaged in natural resource management.

Forestry discussions now shifted towards the "sustainable forest management" (SFM) paradigm, which embraced the notion of sustainable development: 'development to meet the needs of the present without compromising the ability of future generations to meet their own needs' popularized by the Brundtland report Our Common Future (WCED 1987). The previously prevailing notion of sustainability, as applied in forestry for over two centuries, had focused on sustaining timber yields (Wiersum 1999; Kant 2003). SFM then broadened the scope to both present and future generations' needs, to multiple beneficiaries and stakeholders but also to multiple products and services (incl. marketed versus subsistence-oriented products), thus also building the case for MFM (Pearce et al. 2003; Kant 2004). Sustainable forest management has to keep the balance between three main pillars: ecological, economic and socio-cultural. Successfully achieving sustainable forest management will provide integrated benefits to all, ranging from safeguarding local livelihoods to protecting the biodiversity and ecosystems provided by forests, reducing rural poverty and mitigating some of the effects of climate change (Wunder et al. 2007).

Sustainable forest management requires the expertise and advice of forestry professionals and motivation of forest owners. Information on forest resources, effective communication, and supportive organizational structures are also necessary. The stewardship and use of forests and forest lands in a way, and at a rate, that maintains their biodiversity, productivity, regeneration capacity, vitality and their potential to fulfill, now and in the future, relevant ecological, economic and social functions, at local, national, and global levels, and that does not cause damage to other ecosystems (Jylhä 2007).

Criteria and indicators are tools used to define, guide, monitor and assess progress towards sustainable forest management in a given context. Criteria and indicators (CandI) have emerged as a powerful tool in promoting sustainable forest management (SFM) (UNCED 1992.) Criteria define the essential elements against which sustainability is assessed, with due consideration paid to the productive, protective and social roles of forests and forest ecosystems. Each criterion is defined by quantitative or qualitative indicators, which are measured and monitored regularly to determine the effects of forest management interventions over time (Kant 2007). The criterion relates to a key element of sustainability, and may be described by one or more indicators.

Based on the ongoing regional/international processes on criteria and indicators for sustainable forest management there are seven thematic elements of sustainable forest management (FAO 2006): (i) Extent of forest resources, (ii) Biological diversity, (iii) Forest health and vitality, (iv) Productive functions of forest resources, (v) Protective functions of forest resources, (vi) Socio-economic functions, (vii) Legal, policy and institutional framework 2.5 Management system.

Forest management system refers to the organization and controls the creation and maintenance of forest trees and associated output or results. It involves both technical and organizational systems (FAO 2006). The management system must be multiuse-oriented, economically viable and socially accepted, which means high biological and cultural/economic diversity. The enforcement guided by testable safe, minimum standard is the most crucial requirement for achieving sustainability at the present time (Takahashi and Todo 2013). The technical activities involved in forest or tree management systems are utilization of forest tree resources, protection, and maintenance of tree species, distribution of forest products and controlled structure which ensures the proposed activities are coming out as planned (FAO 1991).

Participation has emerged as an important concept in policy making (policy formulation and implementation) in many countries since the 1960s (Beierle and Konisky 2000; Sanoff 2000). It is seen as critical to a shared vision as well as shared ownership of problem and outcome are fundamental to collective action (Johnson et al. 2002) needed for addressing problems with diffuse impacts like environmental degradation. Participation can facilitate accurate understanding of problems and their nature, leading to collective action. The word forest has many meanings but nowadays, usually refers to an association of plants and animals in which followed, not only by government but also in several places in society. The formation of forest policy is continuous process designed to maintain the balance between forest resources of the 
potential supplier on the consumers on the land (Hummel 1984).

Strong policy can force management action for the achievements of forest protection, maintenance, and utilization of forest resource goods and objectives (Mas and Dietsch 2004). But, the forest policy application is limited because of many reasons, like lack of experienced manpower, skilled forestry experts and low education level of the community to understand and promote the conservation and management policies.

\section{CONTRIBUTION OF FORESTS}

\section{Forest as a source of income}

Forestry has had a somewhat ambiguous position in this changing landscape. The relevance of forestry in poverty alleviation seems obvious to some. Large numbers of rural poor people depend on forest resources to some degree, though the definitions used for 'dependence' and the resulting estimates are highly variable and their accuracy is questionable (Calibre 2000).

WCFSD (1999) estimated 350 million of people "depend almost entirely for their subsistence and survival needs on forests" and that another 1 billion depend on forests and trees for fuelwood, food, and fodder. The World Bank (2001) estimated that 1.6 billion people depend to varying degrees on forests for their livelihoods, with 350 million living in or near dense forests depending on them "to a high degree". For our purposes, it is sufficient to recognize that there are large numbers of poor people living in and around forests and using them to some degree. Forest provides important sources of income to many rural people. Forest products such as fuelwood and other products are gathered and traded at local and regional markets and are generally destined for urban consumers.

While this argument may hold in some cases, there are also some inherent limitations. Many NTFPs have very low (often zero) market value. They are accessible to poor people precisely because no one else wants them. In economic terms, many are inferior goods that are substituted by superior products when incomes rise (Arnold 2002), and/or domesticated (Ruiz Pérez et al. 2004). Dove (1993) discusses, and as the institutional economics literature explains (Bardhan 1987), if and when a particular resource increases in value it will attract more powerful actors to try to control the resource and/or the market. In the context of contemporary definitions of poverty that recognize powerlessness as well as low income and wealth, it is easy to realize that the poor are at a major disadvantage in these processes.

\section{Forest as a source of energy, drug, and food security}

Forests are the oldest of the natural resources used by humans. Forests give us many things like fuel, food, wood, etc. in which are very important sources of energy. Forests are sources of food (Jackson and Baker 2010). Wild food is important for food security to 870 million people around the world who do not have access to a sufficient supply of nutritious and safe food. Food security is a condition related to the ongoing availability of food. At the same time, climate change policy is creating incentives to preserve and restore forests, while on the other hand population growth and rising per capita consumption are increasing demands for food and fiber around the world.

Global food demand is projected to grow 59\% to $99 \%$ from 2000 to 2050, depending on actual population and economic growth rates (Southgate et al. 2007). Greater consumption of meat and grain is raising commodity prices and concerns about deforestation (Trostle 2008). National policies supporting bioenergy expansion further amplify deforestation concerns. For instance, recent studies suggest that direct and indirect land-use changes for bioenergy expansion produce net carbon losses from ecosystems, not net gains (Fargione et al. 2008; Gibbs et al. 2008; Searchinger et al. 2008; Piñeiro et al. 2009). Despite existing policies and increased agricultural yields per area, deforestation is still occurring in the tropics and elsewhere.

Plants are the oldest source of drugs. Most of the drugs in ancient times were derived from plants. Almost all parts of the plant are used. There are a hundred chemical substances that have been derived from plants for use as drugs and medicine.

\section{Environmental role of forests}

Forests are one of the most important renewables and assisting resources to maintain the environment. It helps to prevent soil erosion, landslide and soil fertility covering of the upper layers of the soil (FAO 2001). Among the constraints of forests, some are inadequate appreciation of the role and value of forest, and inadequate investment in forestry sector under the state plan, etc.

\section{FOREST CONSERVATION}

The majority of terrestrial biodiversity is found in forests, and half of it is considered to be located in tropical forests (Alfonso et al. 2001). Threats to biodiversity from poor forest management practices are diverse and widespread. Given a global deforestation rate of about 10 million ha per year (FAO 2001) and an unknown but considerably higher area of forests suffering degradation, stepping up efforts in maintaining biodiversity through improving forest management is certainly an important part of an overall strategy.

Forest conservation comprises activities to secure the long-term protection of the environmental services of a forest, notably its biological diversity, soil conservation, watershed regulation and climate regulation. Forests are influenced by climate, landform and soil composition and they exist in a wide variety of forms in the tropical, temperate and boreal zone of the world. Biophysically, the topography (slope) and land scopes of the forest are the main factors for conservation and management. Accordingly, the steepness (sleepy slopped) and unsuitable land feature or land very hilly made the conservation and management activity very difficult (Fischer et al. 2010).

Management systems and strategies are the main factors that can decide and strengthen forest resource conservation. 
To do this one of the systems is community forestry promotion which highly is referred to participatory forest management (FAO 1999). However, PFM system is formed only at idea level which did not strengthen and developed yet. Simply the present management system is very poorly related/linked to sustainable forest management.

There are some emerging practices of forest conservation. For example, in recent years, shade coffee certification programs have attracted increasing attention from conservation and development organizations. Certification programs offer an opportunity to link environmental and economic goals by providing a premium price to producers and thereby contributing to forest conservation (Takahashi and Todo 2013). Although Rainforest Alliances originally worked primarily with producers of larger plantations (Méndez et al. 2010), they also oversaw a certification program that excludes modern industrial coffee producers in an effort to encourage the shaded coffee system to move toward greater sustainability (Mas and Dietsch 2004). The criteria used in such program include shade criteria for tree species richness and composition, tree height, tree density, the number of strata in the canopy, and the percentage of canopy cover (Philpott et al. 2007). However, the significance of the conservation efforts of certification programs remains unclear because of a lack of empirical evidence.

\section{CONSTRAINTS OF FOREST RESOURCES IN ETHIOPIA}

Constraints mean a limitation or restriction of something. There have been a number of constraints in forest that need to be duly addressed and remedial measures are taken so that forest resources could be utilized in the socio-economic development of the state in sustainable manner (Méndez et al. 2010).

Studies have indicated that half of the arable lands in the highlands of Ethiopia (22 million hectares) are already seriously degraded, out of which 2 million hectares have degraded to the extent that they could not sustain crop production $\mathrm{n}$ the future. About 20,000 to 30,000 ha of croplands are also abandoned annually because cropping can no longer be supported by the soil. Indeed, significant areas of marginalized lands are abandoned annually in the country, which ecologists could exploit as an opportunity to catalyze restoration of native flora. There are many approaches to land and vegetation rehabilitation/restoration, each of which depends on the severity of damage to the land resource ((FAO 1986a,b).

Urbanization and related lifestyle changes, as well as the opportunities offered by new information and communication technology, are altering decision-making among family forest owners. Consequently, the approaches and tools of communicating with forest owners are under pressure towards becoming more customer-orientated (Hujala and Tikkanen 2011). The high increase of population numbers enforced the community for agricultural land expansion to achieve their food demand, where there are no other options of getting tree uncultivated fertile land except the forest area, to solve these land scarcity problems. Additionally, many households, where settled in the forest area coming from their original places due to land degradation, unproductivity, soil fertility and homeland capability for good production (Méndez et al. 2010). There is a misunderstanding about forests among the community. They are not well-informed and convinced about the biological, ecological, social and economic importance of forests (Belcher 2005).

In Ethiopia, the poverty and forest governance problems need to be addressed by promoting forest ownership and access rights. This is to promote greater recognition of the rights of local and indigenous groups and give greater attention to land tenure, ownership, and rights-to-resource and access issues. In doing so, it is important to emphasize and enable stakeholder participation in the formulation and implementation of policies, strategies, and programs to foster ownership and long-term sustainability of the resource

The role of forests as an engine of economic growth and development needs to be enhanced. This can be done by increasing investments in plantations (especially in tropical countries), expanding forest certification and overall forest management, and encouraging responsible private sector investments, including community-company partnerships for on-site forest enterprise development, and for market access.

This is also essential to protect vital local and global environmental services and values. Furthermore, creating markets for local ecosystem services such as carbon storage might seize the potentially enormous financing opportunities emerging in the context of global climate change to increase investments for carbon sequestration and avoid deforestation to reduce emissions from deforestation and forest degradation.

In policy context, there is a gap in assisting countries to integrate the global forest agenda into their own national strategies and policies and to harness the development opportunities available. The World Bank's leadership position can be used in the global forest dialogue and take advantage of emerging economic and environmental opportunities (such as the attractiveness of biofuels, for example) to foster sustainable forest management. Integrating forest interdependencies into the design of agriculture, rural development, and natural resources rural poverty alleviation is also as important as the management projects to ensure sustainable economic growth.

\section{OPPORTUNITIES OF FOREST RESOURCES IN ETHIOPIA}

There is a new and increasing emphasis on poverty alleviation and livelihoods improvement in forestry, representing both a challenge and an opportunity (Leskinen et al. 2009). A study which briefly reviews the evolution of the 'livelihoods' issue, analyzes the concept of 'poverty alleviation and discusses means by which forestry can contribute to livelihoods improvement, indicating the role and the potential of a forest product is determined more by 
the socio-economic and environmental context of the production, processing and marketing system than by the physical characteristics of the product itself (Belcher 2005). This is important as new opportunities arise through increased control of resources by local people and new markets for forest products. Helping achieve poverty alleviation through forestry requires protecting poverty mitigation functions, enhancing income and employment options, and taking advantage of opportunities to build and strengthen local institutions through policies and projectlevel interventions.

For appropriate harvesting and growing of few native fodder species, harvesting collection from wood and propagated source of medicinal plants and aromatic plants, and NTFP growing in and around their habitats (Leskinen et al. 2009). They can be involved in mass forestation programs from which they can earn their livelihood.

Women are good personal resources in NTFP enterprise. They can be involved in different utilization and conservation activities they can obtain employment and income collection on harvesting of medicinal and aromatic plants and other non-timber (Leskinen et al. 2009).

For unemployed youth, they have some opportunities in forest by propagation of multipurpose tree species of both timber and nontimber help to establish honey bee boxes for production of honey and wax. They also get income by growing charcoal from small wood and shrubs, to convert forest wastes in to domestic utilization (Belcher 2005).

Lamb and Tomlinson (1994) believe that the first objective of degraded land rehabilitation should be the prevention of further degradation. Plantation forestry can be employed as a tool not only to arrest further site degradation but also to catalyze native forest flora restoration after prolonged anthropogenic disturbances. Tree plantations were initiated and rapidly expanded in the tropical world in the early $20^{\text {th }}$ Century to meet the increasing demand for wood products and relieve the pressures on natural forests. Soon after wide-scale plantation establishments, however, ecologists began to question their stability and future sustainability. The concern stemmed partly from agricultural experience or traces back to historical misconceptions about the influence of plantations of conifers (usually monocultures, sometimes of exotic species) on soil and site processes (Powers 1999).

The questions that were raised against the use of tree plantations usually center on the negative effects of monocultures, i.e. low stability, low resource use efficiency, low level of biodiversity, the tendency to use exotics that were believed to displace indigenous species, and the effects of intensive land management on site conditions including soil and water. These were all sound-looking arguments for the denouncement of plantation expansions, particularly in tropical ecology where biologically rich tropical natural forests are replaced with biologically poor monocultures (Armstrong and van Hansberger 1996; Armstrong et al. 1996). Paradoxical to most of the above negative speculations, today, plantation forestry is getting recognition not only from economic and local wood product supply points of view but also from ecological and biodiversity perspectives. Several recent studies have proven that plantation forests can assist ecological recovery from prolonged anthropogenic disturbances (Powers et al. 1999).

\section{CONCLUSION AND RECOMMENDATION}

In general anthropogenic (human-caused) and lack of goods management policy are the main constraints of forest resource management. Additionally, natural topography and social awareness about forest use cause gradual destruction and minimization of the demographic structure of the forest species which affect hardly the regeneration rate of forest. On the other hand, sustainable forest management includes extent of forest resources, biological diversity, forest health and vitality, productive functions of forest resources, protective functions of forest resources, socio-economic functions and Legal, policy and institutional framework. Generally, for sustainable forest use good management strategy and accurate policy are the core point.

Since forest resource has a multi-direction purpose such as is ecological value, economical, biological, and environmental importance, many consideration and opportunity should be taken by government and other forest agency or forest enterprise to conserve and manage the resource. Our goal should be to conserve, restore, and improve forest productivity, while preserving the quality of life for people and other species on Earth.

\section{REFERENCES}

Alfonso A, Dallmeier F, Granek E, Raven P. 2001. Biodiversity: Connecting with the tapestry of life. Smithsonian Institution/ Monitoring and Assessment of Biodiversity Program and President's Committee of Advisors on Science and Technology. Washington, DC, USA.

Arnold JEM. 2002. Clarifying the links between forests and poverty reduction. Intl For Rev 4 (3): 231-233.

Bardhan P. 1987. The new institutional economics and development theory. World Dev 17 (9): 1389-1395. DOI: 10.1016/0305750X(89)90080-6

Beierle TC, Konisky DM. 2000. Values, conflict, and trust in participatory environmental planning. J Pol Anal Manag 19: 587-602. DOI: 10.1002/1520-6688(200023)19:4<587::AID-PAM4>3.0.CO;2-Q

Belcher BM. 2005. Forest product markets, forests and poverty reduction. Intl For Rev 7 (2): 82-89. DOI: 10.1505/ifor.2005.7.2.82

Cabin RJ, Weller SG, Lorence DH, Cordell S, Hadway LJ. 2002. Effects of microsite, water, weeding, and direct seeding on the regeneration of native and alien species within a Hawaiian dry forest preserve. Biol Conserv 104: 181-190. DOI: 10.1016/S0006-3207(01)00163-X

Calibre Consultants and the Statistical Services Centre [SSC]. 2000. Numbers of forest-dependent people a feasibility study funded by DFID's Forestry Research Programme. University of Reading, UK.

Cotler H, Ortega-Larrocea MP. 2006. Effects of land use on soil erosion in a tropical dry forest ecosystem, Chamela watershed, Mexico. Catena 65: 107-117. DOI: 10.1016/j.catena.2005.11.004

Dove MR. 1993. A revisionist view of tropical deforestation and development. Environ Conserv 20: 17-24. DOI: 10.1017/S0376892900037188

EFAP. 1994. The challenge for development report. Volume 2. Addis Abeba, Ethiopia.

Eshetu Z. 2004. N abundance in soils under young-growth forests in Ethiopia. For Ecol Manag 187: 139-47. DOI: 10.1016/S03781127(03)00315-3 
FAO 1999. Legal bases for the management of forest resources us common Property in Rome. FAO, Rome.

FAO. 2001. Global Forest Resources Assessment 2000 Main Report. FAO, Rome.

FAO. 2006. Global Forest Resource Assessment 2005: Progress Towards Sustainable Forest Management. Food and Agriculture Organization of the United Nations, Rome, Italy.

Fargione J, Hill J, Tilman D, Polasky S, Hawthorne P. 2008. Land clearing and the biofuel carbon debt. Science 319: 1235-1238. DOI: $10.1126 /$ science. 1152747

Fischer AP, Bliss J, Ingemarson F, Lidestav G, Lo "nnstedt L. 2010. From the small woodland problem to ecosocial systems: The evolution of social research on small-scale forestry in Sweden and the USA. Scandinavian J For Res 25: 390-398. DOI: 10.1080/02827581.2010.498386

Food and Agriculture Organization (FAO) of the United Nations. 1986a. Highlands Reclamation Study: Ethiopia. Final Report. Volume I. FAO, Rome.

Food and Agriculture Organization (FAO) of the United Nations. 1986b. Highlands Reclamation Study: Ethiopia. Final Report. Volume II. FAO, Rome.

Gibbs HK, Johnston M, Foley JA, Holloway T, Monfreda C, Ramankutty N, Zaks D. 2008. Carbon payback times for crop-based biofuel expansion in the tropics: The effects of changing yield and technology. Environ Res Lett 3: 034001. DOI: 10.1088/1748-9326/3/3/034001

Hujala T, Jukka T. 2011. Change in forest planner' S Advisory Role." Scandinavian J For Res 26: 466. DOI: 10.1080/02827581.2011.579996

Jackson RB, Justin SB. 2010. Opportunities and constraints for forest climate mitigation. Bioscience 60: 9: 698-707. DOI: 10.1525/bio.2010.60.9.7

Johnson N, Ravnborg HM, Westermann O, Probst K. 2002. Use participation in watershed management and research. Water Pol 3 (6): 507-520. DOI: 10.1016/S1366-7017(02)00014-4

Jylhä L. 2007. Forest management associations-Value from Cooperation for forest owners. Unasylva 58 (228): 44-47.

Kant S. 2003. Extending the boundaries of forest economics. For Pol Econ 5: 39-56. DOI: 10.1016/S1389-9341(02)00045-X

Kant S. 2004. Economics of sustainable forest management. For Pol Econ 6: 197-203.

Kant S. 2007. Economic perspectives and analyses of multiple forest values and sustainable forest management. For Pol Econ 9: 733-740. DOI: $10.1016 /$ j.forpol.2005.11.003

Lamb D, Tomlinson M. 1994. Forest rehabilitation in the Asia-Pacific region: past lessons and present uncertainties. J Trop For Sci 7 (1): 157-170.

Leskinen LA. 2006. Adaptation of the regional forestry administration to national forest, climate change and rural development policies in Finland. Small-Scale For Econ Manag Pol 5: 231-247. DOI: 10.1007/s11842-006-0012-6

Leskinen P, Hujala T, Tikkanen J, Kainulainen T, Kangas A, Kurttila M. 2009. Adaptive decision analysis in forest management planning. For Sci 55: 95-108. DOI: 10.1093/forestscience/55.2.95

Mas AH, Dietsch TV. 2004. Linking shade coffee certification to biodiversity conservation: butterflies and birds in Chiapas, Mexico. Ecol Appl 14: 642-654. DOI: 10.1890/02-5225
Méndez VE, Bacon CM, Olson M, Morris KS, Shattuck A. 2010. Agrobiodiversity and shade coffee smallholder livelihoods: a review and synthesis of ten years of research in Central America. Prof. Geogr 62: 357-376. DOI: 10.1080/00330124.2010.483638

Pearce D, Putz FE, Vanclay JK. 2003. Sustainable forestry in the tropics: panacea or folly? For Ecol Manag 172: 229-247. DOI: 10.1016/S03781127(01)00798-8

Philpott SM, Bichier P, Rice R, Greenberg R. 2007. Field-testing ecological and economic benefits of coffee certification programs. Conserv Biol 21: 975-985. DOI: 10.1111/j.1523-1739.2007.00728.x

Piñeiro G, Jobbágy EG, Baker J, Murray BC, Jackson RB. 2009. Set-asides can be better climate investment than corn ethanol. Ecol Appl 19: 277 282. DOI: $10.1890 / 08-0645.1$

Powers RF. 1999: On the sustainable productivity of planted forests. New For 17: 253-306. DOI: 10.1023/A:1006555219130

Ruiz-Pérez M, Belcher B, Achdiawan R, Alexiades M, Aubertin C, Caballero J, Campbell B, Clement C, Cunningham A, Fantini A, De Foresta H, Garcia Fernandez C, Gautam K, Hersch Martinez P, De Jong W, Kusters K, Kutty M, López C, Martinez FUM, Nair M,Ndoye TKR, Ocampo O, Rai R, Ricker N, Schreckenberg M, Shackleton K, Shanley S, Sunderland P, Youn Y. 2004. Markets drive the specialization strategies of forest peoples. Ecol Soc 9 (2): 4. DOI: 10.5751/ES-00655-090204

Sanoff H. 2000. Community participation methods in design and planning. John Wiley and Sons, New York.

Searchinger T, Heimlich R, Houghton RA, Dong F, Elobeid A, Fabiosa J, Tokgoz S, Hayes D, Yu TH. 2008. Use of U.S. croplands for biofuels increases greenhouse gases through emissions from land-use change. Science 319: 1238-1240. DOI: 10.1126/science.1151861

Southgate DD, Graham D, Tweeten D. 2007. The World Food Economy. Wiley, New York

Takahashi R, Yasuyuki T. 2013. The impact of a shade coffee certification program on forest conservation: A case study from a wild coffee forest in Ethiopia. J Environ Manag 130: 48-54. DOI: 10.1016/j.jenvman.2013.08.025

Trostle R. 2008. Global agricultural supply and demand: factors contributing to the recent increase in food commodity prices. US Department of Agriculture Economic Research Service. Report WRS0801.

UNCED [United Nations Conference for Environment and Development]. 1992.Sustainable forest management and its thematic elements. Rio de Janeiro, Brazil

Wang S. 2004. One hundred faces of sustainable forest management. For Pol Econ 6, 205-213. DOI: 10.1016/j.forpol.2004.03.004

WCED.1987. Our Common Future. Oxford University Press, Oxford.

WCFSD. 1999. Our forests, our future. World Commission on Forests and Sustainable Development. Cambridge University Press, Cambridge.

Wiersum KF. 1999. Social Forestry: Changing Perspectives in Forestry Science or Practice. [Dissertation]. Agricultural University, Wageningen.

World Bank. 2001. A revised forest strategy for the World Bank Group. World Bank, Washington D.C.

Wunder S, Manuel R, Carmen G. 2007. Forest ecology and management is multiple-use forest management widely implementable in the tropics. For Ecol Manag 256: 1468-1476. DOI: 10.1016/j.foreco.2008.04.029 